\title{
Pengembangan Media Pembelajaran Tari Topeng Berbasis Android dengan Metode Analysis Design Development Implementation and Evaluation
}

\author{
Ade Irma Purnamasari ${ }^{1 *}$, Andi Setiawan ${ }^{2}$, Kaslani $^{3}$ \\ ${ }_{1,2}^{1, P r o g r a m}$ Studi Teknik Informatika, STMIK IKMI Cirebon \\ ${ }^{3}$ Program Studi Komputerisasi Akuntansi, STMIK IKMI Cirebon \\ 1,2,3Jln. Perjuangan No. 10 B Majasem Cirebon, 45135, Indonesia \\ E-mail: irma2974@yahoo.com ${ }^{1}$, 42andisetiawan@gmail.com ${ }^{2}$, kas_kas123@yahoo.com ${ }^{3}$
}

\section{Info Naskah:}

Naskah masuk: 14 November 2020

Direvisi: 15 Maret 2021

Diterima: 15 Maret 2021

\begin{abstract}
Abstrak
Tari Topeng merupakan satu dari kesenian tradisional Cirebon yang ada di Indonesia dan memiliki keanekaragaman jenis serta makna sesuai dengan simbol-simbol menggambarkan karakter seperti pada cerita kerakyatan. Generasi muda dalam melakukan aktifitasnya tidak lepas dari menggunakan teknologi internet, salah satunya sosial media, sehingga mempengaruhi kurang peduli terhadap seni dan tradisi yang telah melekat di masyarakat. Dari permasalahan tersebut perlu dibuat media pembelajaran Tari Topeng dengan memanfaatkan teknologi android. Penelitian ini menggunakan metode ADDIE melalui tahapan Analysis, Design, Development, Implementation, dan Evaluation sebagai pedoman dalam membangun perangkat pembelajaran. Hasil penelitian ini adalah aplikasi media pembelajaran Tari Topeng berbasis android untuk mengenalkan Tari Topeng mulai dari sejarah, deskripsi, jenis tari, cara menari Tari Topeng, dan kuis untuk mengevalusi pemahaman pembelajaran. Dengan adanya media pembelajaran ini dapat memberikan kemudahan dalam mempelajari Tari Topeng di kalangan siswa maupun generasi muda lainnya. Dari hasil pengujian menggunakan black box menunjukan bahwa fungsi yang ada pada aplikasi telah berjalan sesuai dengan fungsinya, adapun hasil pengujian kepada responden diperoleh nilai sebesar $84,27 \%$ dengan kriteria baik terhadap aplikasi sehingga aplikasi ini dapat digunakan sebagai media pembelajaran Tari Topeng.
\end{abstract}

\section{Keywords:}

learning media;

mask dance;

android;

addie:

\begin{abstract}
Mask Dance is one of Cirebon's traditional arts in Indonesia and has a variety of types and meanings in accordance with the symbols depicting characters such as in popular stories. The young generation in their activities cannot be separated from using internet technology, one of which is social media, so that it affects their less concern for art and traditions that have been inherent in society. From these problems, it is necessary to make Mask Dance learning media by utilizing android technology. This study uses the ADDIE method through the stages of Analysis, Design, Development, Implementation, and Evaluation as a guide in building learning tools. The results of this study are an Android-based application of Mask Dance learning media to introduce Mask Dance starting from history, descriptions, types of dance, how to dance to Mask Dance, and quizzes to evaluate understanding of learning. With this learning media, it can make it easier for students to learn mask dance among students and other young generations. From the test results using a black box, it shows that the functions in the application have been running according to their function, while the test results to the respondents obtained a value of $84.27 \%$ with good criteria for the application so that this application can be used as a medium for learning Mask Dance.
\end{abstract}

*Penulis korespondensi:
Ade Irma Purnamasari

E-mail: irma2974@yahoo.com 


\section{Pendahuluan}

Seni Tari Topeng merupakan salah satu kesenian peninggalan leluhur yang secara turun temurun diteruskan kepada generasi muda khususnya di Cirebon, seni Tari Topeng Cirebon memiliki sejarah dan makna sesuai dengan simbol-simbol yang dikenakan pada tari yang menggambarkan karakter seperti pada cerita kerakyatan, yang ditandai dengan penarinya yang berperan sebagai tokoh-tokoh dalam ceritera dengan mengenakan topeng [1]. Tari Topeng sebagai bentuk seni pertunjukan tradisional Cirebon yang memiliki ciri khas topeng, dan memiliki karakter nilai pendidikan pada topeng tersebut [2].

Berdasarkan data di Dinas Pemuda dan Olahraga Kebudayaan dan Pariwisata (Disporbudpar) terdaftar ada 199 sanggar seni budaya, kini hanya 11 sanggar seni tari yang masih aktif, kurangnya perhatian pemerintah dan minimnya wadah kegiatan untuk melestarikan seni budaya Cirebon, penurunan minat generasi muda dalam melestarikan seni budaya Cirebon dikarenakan kurangnya animo masyarakat dan lebih memilih bentuk kesenian lainnya, karena budaya asing mudah masuk dan terserap dengan adanya media internet, televisi dan media massa, khususnya generasi muda dengan segala aktifitasnya tak lepas dari menggunakan teknologi terutama internet salah satunya sosial media.

Generasi muda merupakan cikal bakal sebagai penerus bangsa maka perlunya mengenalkan seni budaya pada generasi milenial dalam pendidikan formal maupun non formal sehingga dapat mengenal dan mencintai serta melestrasikan seni budaya bangsa, karena kesukaannya dengan hal-hal yang baru dan kecanggihan teknologi yang ada pada saat ini salah satunya teknologi internet dan android.

Smartphone berbasis android mempunyai kemampuan hampir sama dengan komputer, dan telah banyak digunakan karena bersifat open source serta memiliki platform terbuka bagi pengembang aplikasi [3], aplikasi android dapat memfasilitasi proses pembelajaran [4], sehingga jumlah pengguna smartphone di Indonesia setiap tahun semakin meningkat dengan pesat, berdasarkan data yang dikemukaan Katadata Indonesia [5], seperti pada gambar 1.

Teknologi smartphone berbasis android dapat dimanfaatkan pengguna untuk proses pembelajaran dan dapat dikembangkan sebagai media pembelajaran yang interaktif [6], media pembelajaran berbasis android akan menjadi lebih menarik dan ringkas [7] dalam menyajikan materi melalui media pembelajaran biologi berbasis android dapat digunakan kapan dan dimana saja terdapat keefektifan dengan hasil belajar siswa [8].

Pengembangan media pembelajaran untuk mengenalkan seni tari topeng Cirebon yang menarik dan dinamis. Dalam pengembangan media pembelajaran ini menggunakan metode ADDIE (Analysis, Design, Development, Implementation, dan Evaluation) [9][10] untuk dijadikan model desain pembelajaran dan layak digunakan sebagai media pembelajaran termasuk kategori sangat baik 85,83\% [11]. Metode ADDIE dapat menghasilkan aplikasi pembelajaran huruf dan angka dan dapat membantu proses pembelajaran menjadi menyenangkan dengan nilai rata-rata $82,6 \%$ [12].
Penggunaan media pembelajaran berbasis android untuk materi biologi dengan interpretasi sangat baik dan dinyatakan layak secara keseluruhan dengan rata-rata nilai sebesar 84\% [13]. Penelitian [14] adanya peningkatan hasil belajar dan layak sebagai media pembelajaran dengan memanfaatkan mobile learning berbasis android dengan peningkatan belajar mencapai nilai rata-rata pretest 65,46 dan posttest mencapai nilai 79,53. Pemanfaatan Media pembelajaran mata kuliah terpadu berbasis android layak digunakan, hasil diperoleh dari respon mahasiswa dengan nilai rata-rata 91,67\% dengan kriteria sangat kuat [15].

Dari penelitian yang telah dilakukan sebelumnya dapat disimpulkan bahwa dengan mengembangkan media pembelajaran berbasis android dapat membantu pendidik dalam menyampaikan materi dan meningkatkan motivasi belajar siswa. Perbedaan pada penelitian ini dengan penelitian sebelumnya adalah penelitian ini fokus pada masalah kearifan lokal Indonesia khususnya di daerah Cirebon yang berkaitan dengan kesenian tradisional yaitu tari topeng, dimana kesenian ini mulai kurang diminati oleh generasi muda, hal ini mendorong dilakukan penelitiaan untuk mengembangkan media pembelajaran tari Topeng dengan memanfaatkan teknologi android yang memiliki fitur aksesbilitas dan kompatibel. Penelitian ini dalam mengembangkan aplikasi menggunakan metode ADDIE dengan tahapannya analysis, design, development, implementation, dan evaluation [12]. Sebagai dasar mengembangkan interface aplikasi ini menggunakan storyboard untuk menggambarkan konsep pembelajaran yang menarik, selanjutnya media pembelajaran tari topeng berbasis android diuji secara fungsionalitasnya dan dievaluasi oleh pengguna untuk menilai fitur, materi/konten, dan aksesbilitas aplikasi.

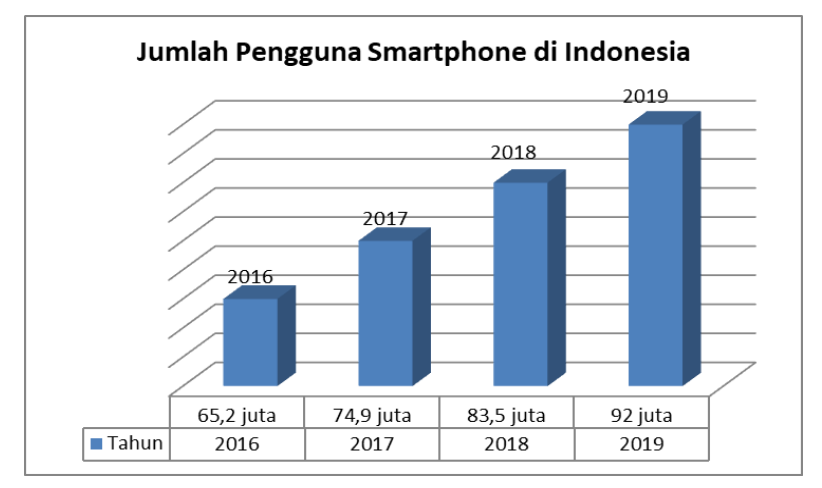

Gambar 1. Grafik pengguna smartphone

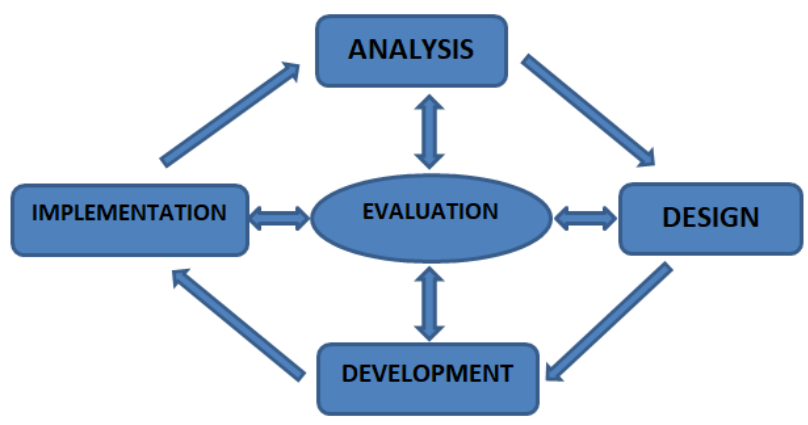

Gambar 2. Metode ADDIE 


\section{Metode Penelitian}

Penelitian ini menggunakan metode ADDIE dalam perancangan media pembelajaran. Metode ADDIE terdiri dari tahapan: Analysis, Design, Development, Implementation, dan Evaluation [12]. Adapun tahapantahapan metode ADDIE seperti pada gambar 2. Pada tahapan pertama yaitu tahap analysis ini dilakukan untuk menganalisis kelayakan dan persyaratan pengembangan metode pembelajaran, mengklarifikasi masalah yang dihadapi memerlukan solusi media pembelajaran berbasis android, menentukan tujuan materi pembelajaran yang berkaitan dengan Tari Topeng, dan menentukan teknologi android agar pengguna mudah mengakses materi pembelajaran Tari Topeng dimana dan kapan saja, proses ini dilakukan melalui studi literature dan wawancara dengan pelatih, pemilik ganggar, dan siswa.

Tahapan yang kedua adalah tahap design untuk melakukan proses menetapkan materi pembelajaran, menentukan metode pembelajaran, menyusun kerangka, dan storyboard media pembelajaran, serta membuat desain prototipe media pembelajaran Tari Topeng berbasis android. Tahapan yang ketiga yaitu tahap development merupakan tahap proses kegiatan realisasi rancangan produk, meliputi mengembangkan materi pembelajaran Tari Topeng, mengembangkan perangkat pembelajaran berbasis android menggunakan aplikasi android studio, adobe photoshop, coreldraw, dan perangkat lunak pendukung lainnya. Dalam proses pembuatan media pembelajaran diawali dengan membuat konten pembelajaran, objek-objek 2D, video Tari Topeng, dan kuis. Selanjutnya pembuatan aplikasi dengan menggunakan android studio disesuaikan dengan storyboard yang telah dirancang sehingga menghasilkan menjadi produk untuk dilakukan pengujian.

Tahap implementation, dilakukan setelah tahap development selesai. Pada tahapan ini merupakan proses menerapkan media pembelajaran Tari Topeng kepada pengguna, dan penerapan media pembelajaran menggunakan smartphone android untuk menjalankan aplikasi pembelajaran Tari Topeng.

Tahap evaluation, tahapan ini dilakukan untuk mengevaluasi isi, materi dan aplikasi yang telah dibuat untuk mengevaluasi penggunaan aplikasi pada pengguna dan menguji konten pada aplikasi oleh para ahli bidang teknologi pembelajaran dan bidang seni Tari Topeng.

\section{Hasil dan Pembahasan}

Media pembelajaran Tari Topeng berbasis android dapat membuat proses belajar dan pelatihan Tari Topeng menjadi lebih efektif dan menyenangkan dengan disajikan dalam bentuk visual dengan tujuan sebagai alat bantu pendidik/pelatih dalam menyampaikan materi dan dapat dijadikan bahan latihan tambahan yang dapat digunakan oleh siswa dimana saja dan kapan saja. Penelitian ini menggunakan model ADDIE.

\subsection{Analisis Sistem}

Pada tahapan ini melakukan wawancara kepada pendidik/pelatih dan pemilik sanggar tari, serta melakukan studi literatur terkait dengan kesenian tari topeng, wawancara dilakukan dengan 2 orang pelatih dari sanggar seni dan 2 orang ahli dalam bidang seni Tari Topeng. Dari hasil analisis yang dilakukan mendapat tanggapan yang baik dan aplikasi yang telah dikembangkan dapat digunakan untuk membantu para pelatih menyampaikan materi dan ketrampilan praktek menari. Aplikasi ini juga dapat digunakan oleh siswa dan pendidik/pelatih.

Pada media pembelajaran terdapat materi meliputi (i) sejarah perkembangan Tari Topeng, (ii) deskripsi Tari Topeng, (iii) jenis tari dan topeng, (iv) video ketrampilan menari, (v) lokasi sanggar seni, dan (vi) kuis.

Dari hasil wawancara dengan narasumber, bahwa jumlah topeng yang digunakan ada 9 buah, namun yang dijadikan topeng untuk tarian hanya 5 buah, sedangkan 4 topeng lainnya digunakan untuk pementasan cerita atau lelakon. Maka dipilih Tari Topeng yang akan dijadikan materi pembelajaran ada 5 jenis tari yaitu Tari Topeng panji, Tari Topeng samba, Tari Topeng rumyang, Tari Topeng tumenggung, dan Tari Topeng kelana.

\subsection{Design Sistem}

Pada tahapan ini dilakukan merancang materi yang dibutuhkan, merancang scenario sistem, membangun storyboard, merancang interface, membuat gambar dan video sesuai dengan tarian serta merancang kuis pembelajaran. Materi yang dibutuhkan dalam membuat media pembelajaran tari topeng ini yaitu sejarah perkembangan tari topeng di Cirebon, jenis tariannya, dan cara menari tari topeng yang sesuai dengan karakter. Objek yang digunakan dalam pengembangan media pembelajaran tari berupa topeng, karakter tarian, pakaian, dan penari, objek tersebut dirancang dalam bentuk 2D.

Perancangan aplikasi media pembelajaran Tari Topeng diawali dengan pemodelan yang menggambarkan aksi yang akan dibangun, dengan menggunakan usecase diagram seperti pada gambar 3. Di dalam aplikasi pembelajaran Tari Topeng terdapat satu aktor yang dapat penggunakan aplikasi. Aktivitas aktor digambarkan dengan use case yang terdiri dari sejarah, deskripsi, jenis, video, lokasi, dan kuis. Deskripsi memiliki relasi dengan menu deskripsi yang sifatnya include dan deskripsi tari berelasi include terhadap menu deskripsi, untuk menampilkan deskripsi tari dapat dilakukan dengan menjalankan menu deskripsi lebih dahulu untuk mendapatkan materi tentang deskripsi Tari Topeng. Use case jenis tari memiliki relasi dengan use case menu jenis tari untuk menanpilkan jenis Tari Topeng berdasarkan topeng yang dikenakan oleh penari. Use case tampil video tari memiliki include dengan menu video untuk menjalankan video Tari Topeng berdasarkan jenis Tari Topeng. Use case kuis berelasi dengan use case tampil kuis, karena ketika menjalankan kuis akan tampil kuis yang terdiri dari sepuluh soal latihan untuk mengetahui kemampuan belajar siswa. 


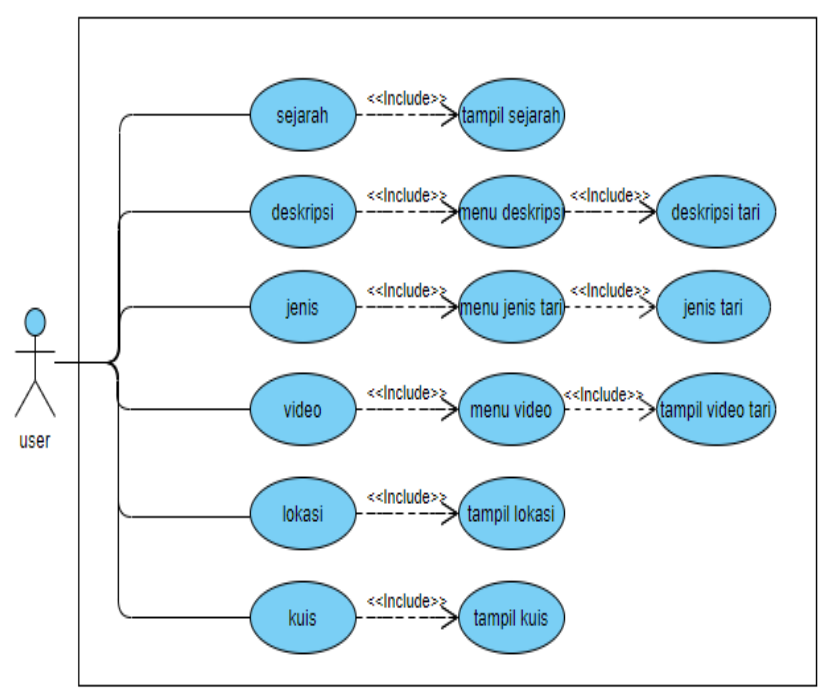

Gambar 3. Usecase diagram

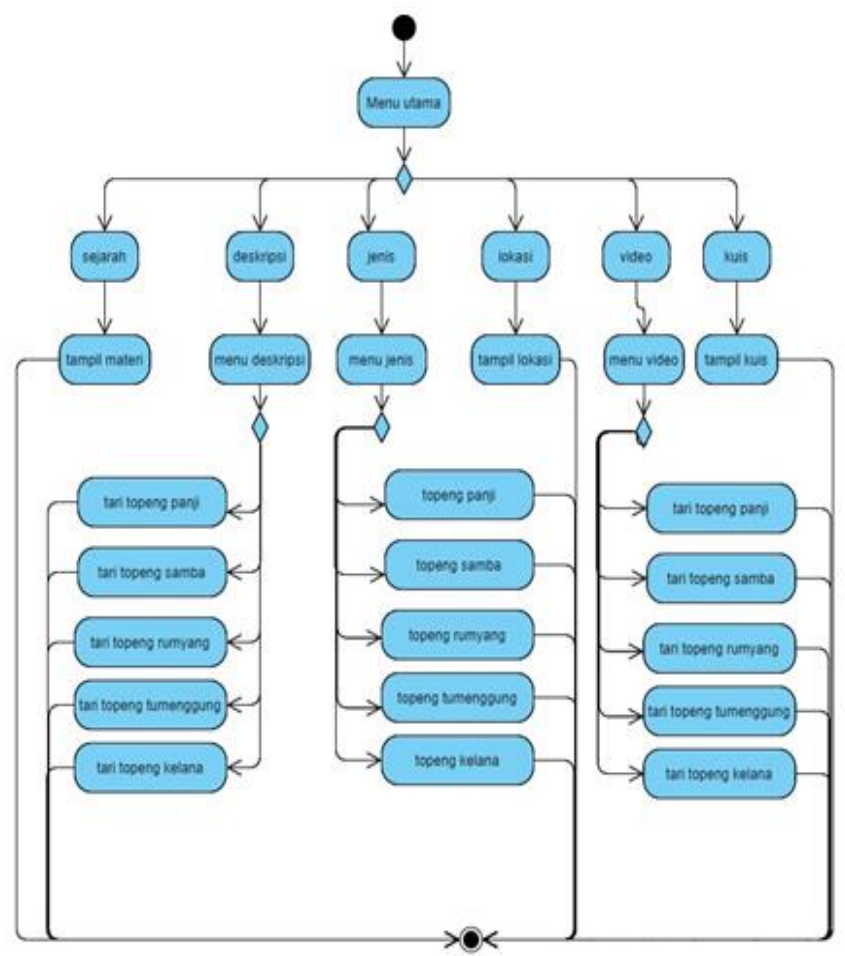

Gambar 4. Activity Diagram

Pemodelan untuk menjelaskan proses dan urutan aktivitas-aktivitas dalam program, dirancang dengan dengan activity diagram seperti gambar 4. Terdapat aliran aktivitas awal, pencabangan, dan akhir. Sebelum materi diimplementasikan ke dalam sistem, lebih dahulu melakukan perancangan sistem menggunakan storyboard yang dijadikan rancangan membangun aplikasi seperti gambar 5 .

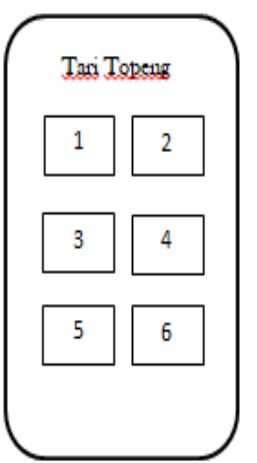

(a)

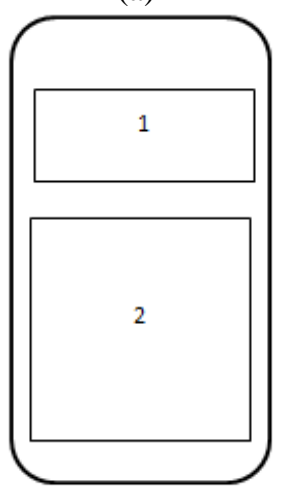

(d)

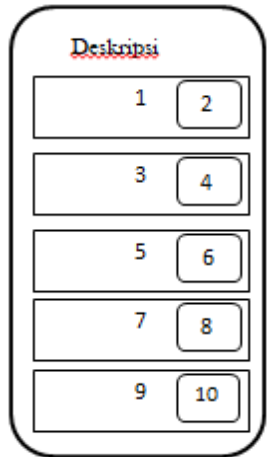

(b)

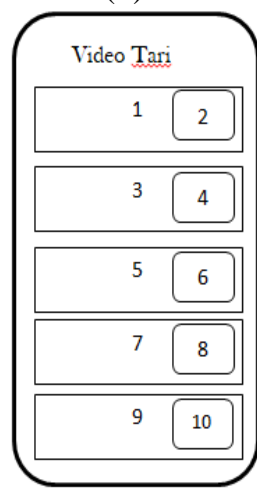

(e)

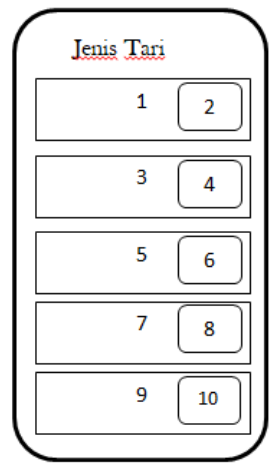

(c)

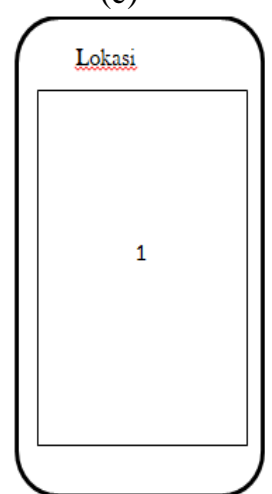

(f)
Gambar 5. Rancangan storyboard

Pada gambar 5 yaitu: (a) rancangan tampilan menu utama untuk ditampilkan pertama kali aplikasi dijalankan terdapat enam sub menu yaitu sejarah, deskripsi, jenis, video, lokasi, dan kuis (b) adalah tampilan menu deskripsi yang memiliki lima pilihan sub-menu untuk menampilkan deskripsi tari yaitu deskripsi tari Panji, Samba, Rumyang, Tumenggung, dan Kelana (c) merupakan tampilan menu jenis yang memiliki lima sub menu untuk menampilkan jenis tari Panji, Samba, Rumyang, Tumenggung, dan Kelana, (d) rancangan untuk menampilkan deskripsi tari berisi materi dan dilengkapi dengan gambar penari dengan mengenakan topeng, (e) rancangan menu video yang memiliki lima sub menu yaitu untuk menampilkan video video tari topeng Panji, Samba, Rumyang, Tumenggung, dan Klana, (f) merupakan tampilan peta untuk menampilkan lokasi dan nama-nama sanggar seni tari yang ada di wilayah Cirebon.

Setelah membuat rancangan storyboard, dilanjutkan dengan merancang antarmuka aplikasi media pembelajaran untuk memudahkan dalam implementansi dalam perangkat lunak android

\subsection{Development System}

Dalam membangun aplikasi diperlukan peralatan pendukung untuk menyajikan hasil rancangan aplikasi Pada tahapan ini dilakukan untuk menyiapkan tools pengembangan aplikasi yaitu perangkat keras dan perangkat lunak android studio, photoshop, dan coreldraw dan audio. Pembuatan aplikasi dimulai dari pembuatan objek 2D berupa topeng dan penari topeng berdasarkan karakter Tari Topeng yang terdiri dari Topeng Panji, 
Samba, Rumyang, Tumenggung, dan Kelana. Tahapan selanjutnya menambahkan narasi, deskripsi, jenis tari, lokasi, video, dan kuis. Penambahan lokasi untuk memberikan informasi sanggar seni yang ada di Cirebon dengan memanfaatkan google map. Untuk penambahan video yang telah dibuat sebelumnya video tarian topeng diupload ke media you tube untuk mendapatkan link penayangan tarian topeng. Tahap terakhir yaitu pembuatan kuis yang terdiri dari sepuluh soal untuk mengetahui pengetahuan dan kemampuan siswa terhadap Tari Topeng Cirebon.

Dari tahapan desain yang telah dilakukan, selanjutnya dikembangkan ke dalam aplikasi android studio dan menambahkan kode program untuk membuat menu utama berdasarkan rancangan sebelumnya. Gambar 6 adalah tampilan pengembangan menu utama pada aplikasi android studio.

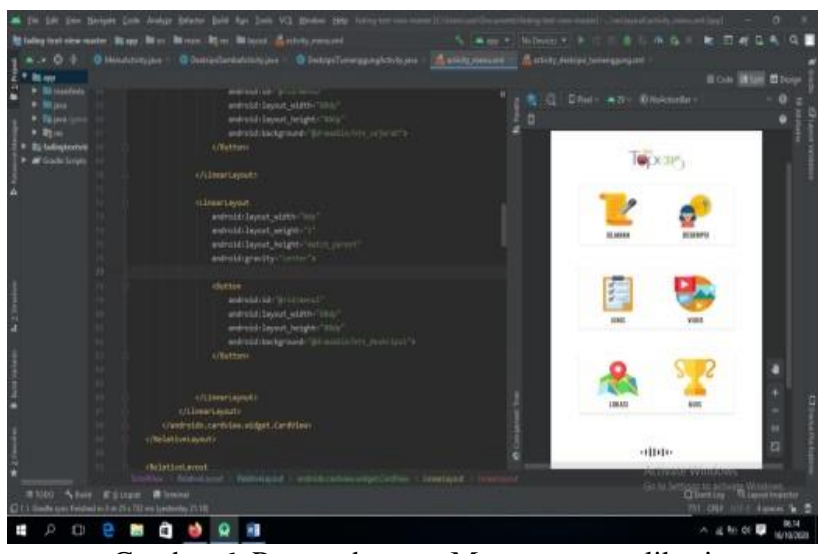

Gambar 6. Pengembangan Menu utama aplikasi

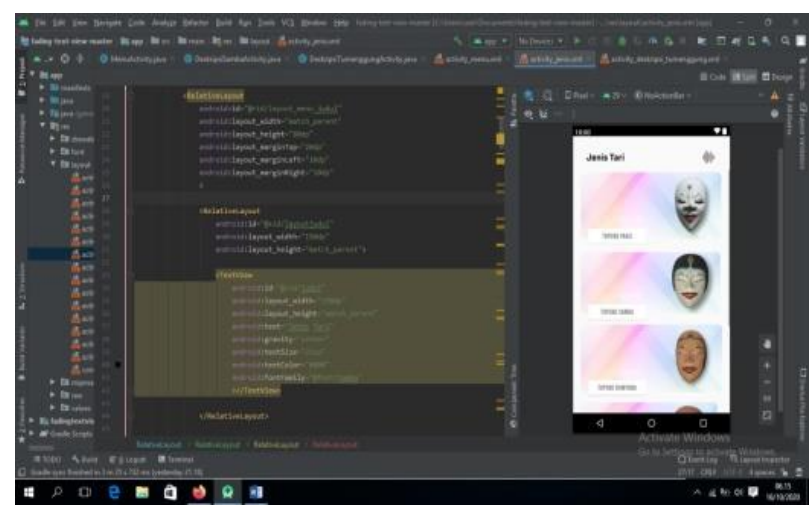

Gambar 7. Pengembangan Menu jenis tari

Gambar 7, adalah tampilan proses pengembangan menu jenis tari, pada pengembangan ini menambahkan objek 2D berupa objek topeng karakter. Gambar 8 adalah proses pengembangan deskripsi Tari Topeng, dengan menambahkan uraian tentang Tari Topeng dan objek 2D berupa gambar penari topeng.

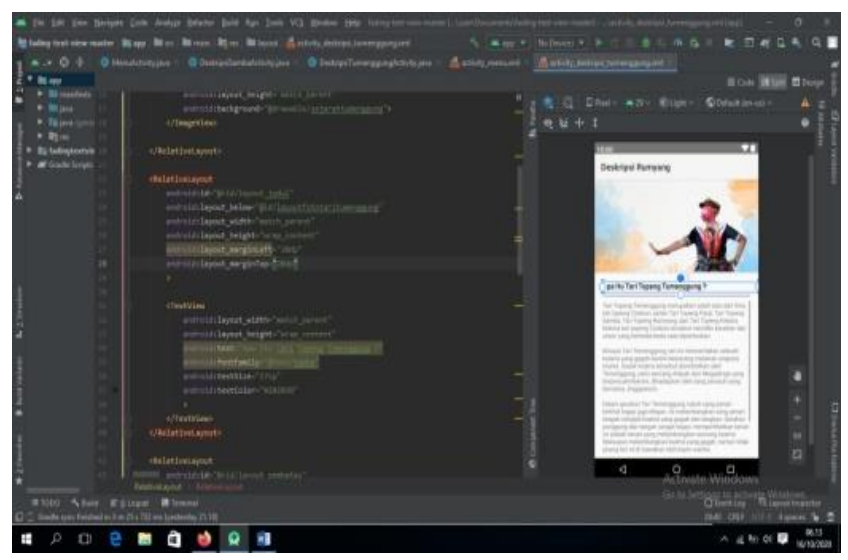

Gambar 8. Hasil Pengembangan Deskripsi Tari

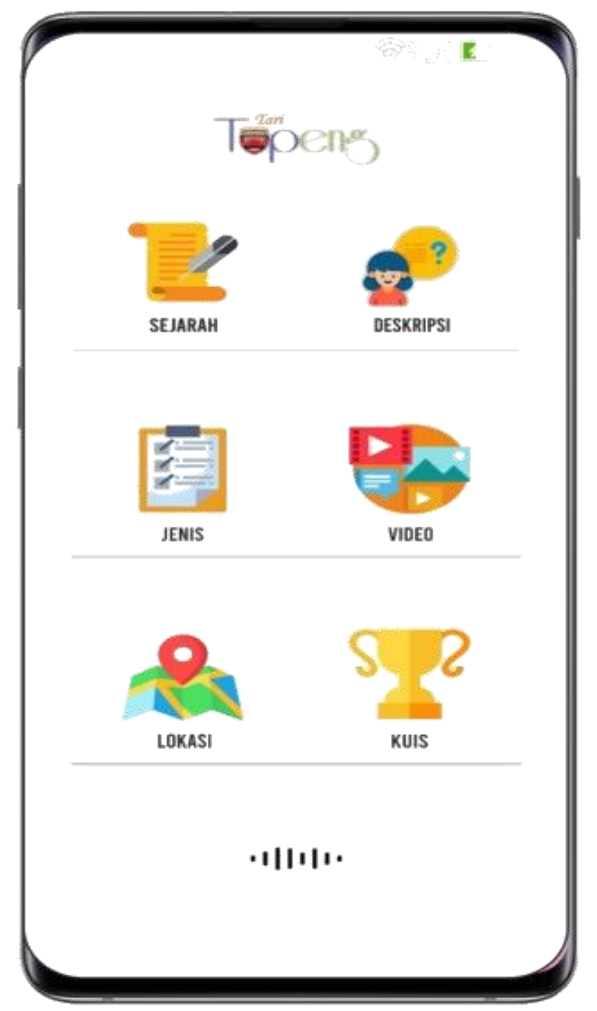

Gambar 9. Halaman Menu Utama Aplikasi Tari Topeng

\subsection{Implementasi Sistem}

Tahap implementasi merupakan lanjutan dari tahapan pengembangan, hasilnya adalah aplikasi media pembelajaran Tari Topeng yang dapat diakses melalui smartphone, adapun tampilan dari hasil aplikasi seperti gambar dibawah ini. Tampilan pertama pada aplikasi seperti pada gambar 9 adalah tampilan menu utama. Pengguna dapat memilih menu untuk memasuki content selanjutnya sesuai dengan pilihan yang terdiri dari menu sejarah, deskripsi, jenis, video, lokasi, dan kuis. Jika dipilih halaman deskripsi pengguna akan masuk ke halaman sub menu deskripsi tari selanjutnya pengguna dapat memilih menu deskripsi tari sesuai dengan pilihannya untuk melihat deskripsi Tari Topeng. Menu deskripsi terdiri dari menu 
Tari Topeng Panji, Samba, Rumyang, Tumenggung, dan kelana, terlihat pada gambar 10.

Selanjutnya jika dipilih salah satu menu deskripsi Tari Topeng akan menampilkan isi materi dari tarian Topeng Panji, Samba, Rumyang, Tumenggung, dan Kelana, berikut contoh tampilan salah satu deskripsi tari yaitu Tari Topeng Panji, seperti terlihat pada gambar 11. Pada gambar 12 menampilkan menu jenis Tari Topeng, jika dipilih salah satu jenis tari akan menampilkan uraian tentang karakter tari berdasarkan topeng yang dikenakan penari.

Pada Gambar 13 menampilkan peta yang akan dilihat oleh pengguna melalui akses layanan API Google Map untuk menampilkan lokasi dan nama-nama sanggar seni tari yang berbeda-beda di wilayah Cirebon, halaman ini akan ditampilkan setelah pengguna memilih menu lokasi. Bagian akhir dari aplikasi ini adalah Kuis, pengguna dapat mengakses kuis dan menjawab semua pertanyaan yang ada di aplikasi, pertanyaan pada kuis terdiri dari sepuluh soal, seperti pada gambar 14 .

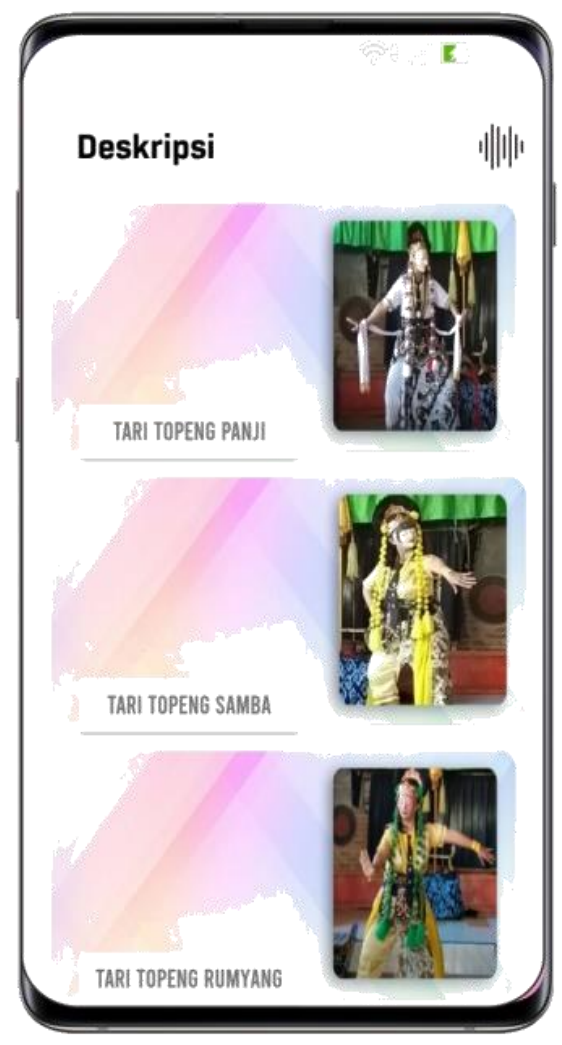

Gambar 10. Halaman Menu Deskripsi Tari

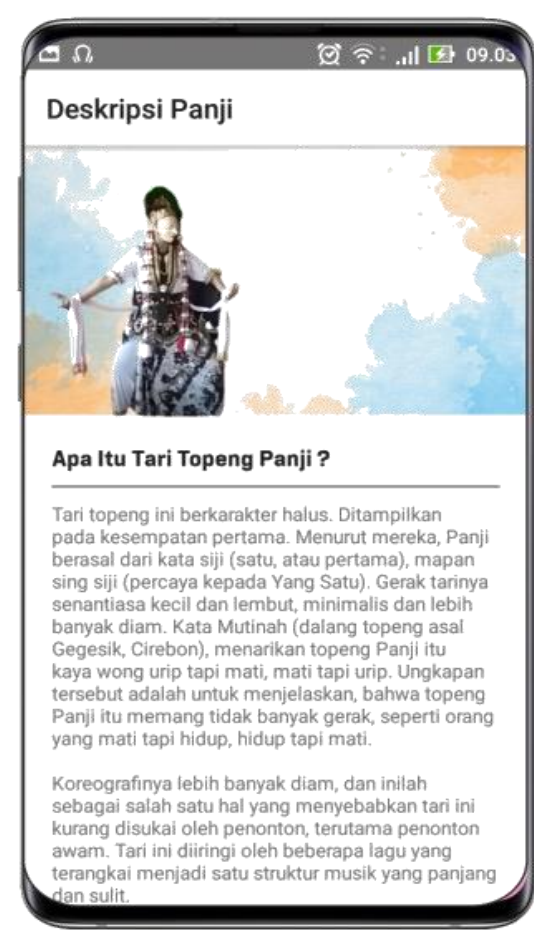

Gambar 11. Halaman Deskripsi Tari Topeng Panji

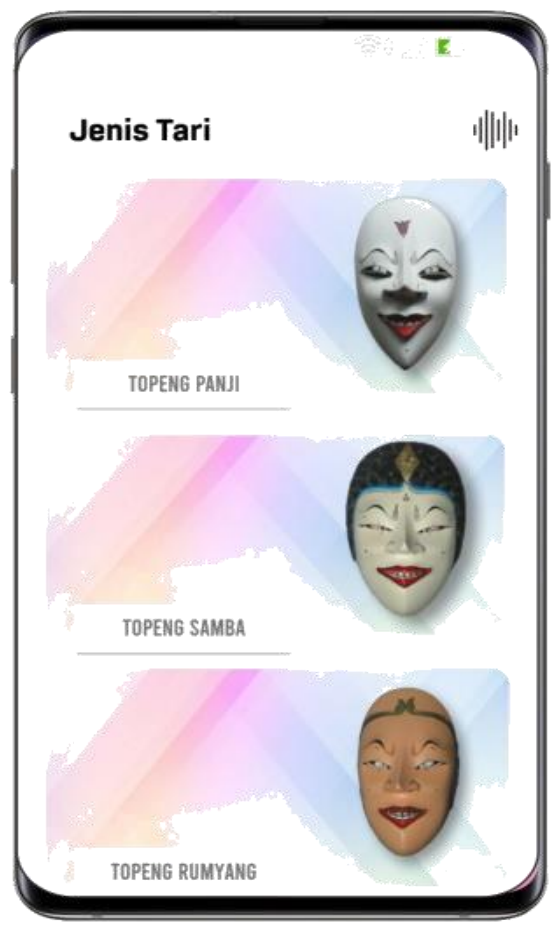

Gambar 12. Halaman Menu Jenis Tari 


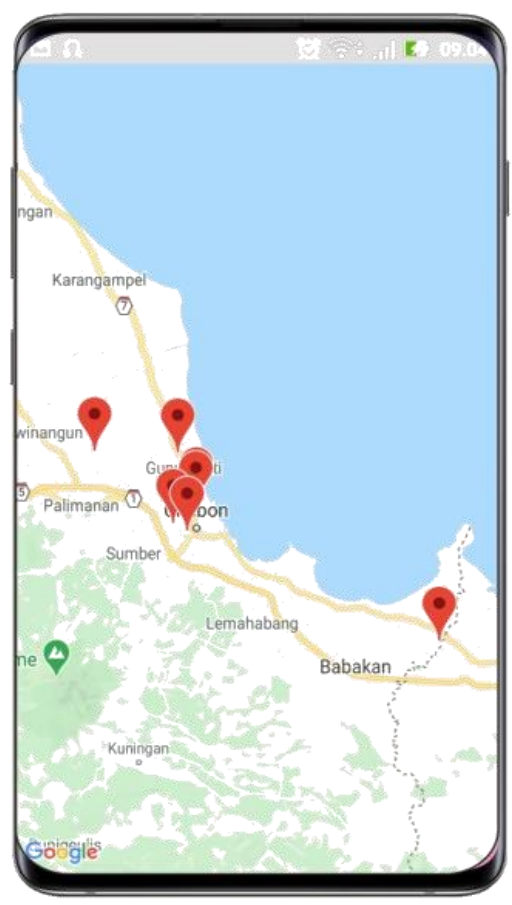

Gambar 13. Halaman Lokasi Sanggar Seni Tari

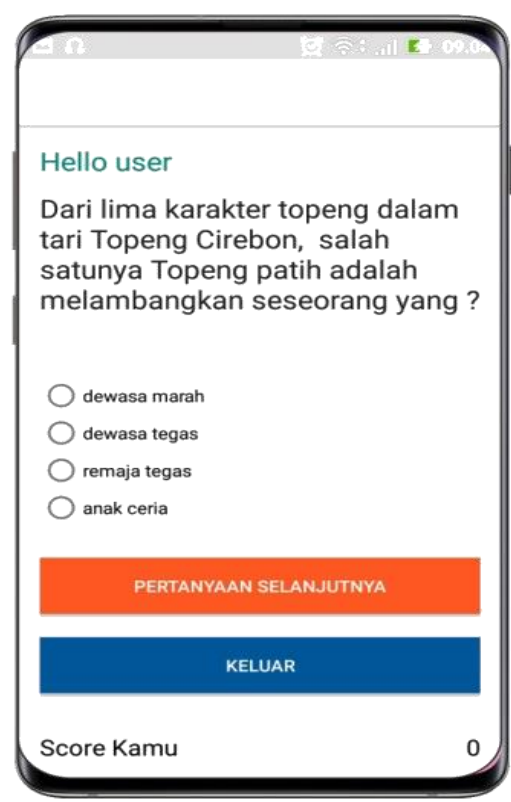

Gambar 14. Halaman Kuis

Selanjutnya aplikasi ini diimplementasikan kepada 15 siswa dan dijadikan responden yang belum memiliki ketrampilan Tari Topeng, dan kepada dosen yang ahli dibidang teknologi android, dan pakar dalam bidang seni dan budaya Cirebon.

\subsection{Hasil Evaluasi Sistem}

Dari hasil implementasi selanjutnya dilakukan proses evaluasi. Proses pengujian awal dilakukan dengan pengujian black box untuk menguji kinerja aplikasi pembelajaran dan menguji fungsionalitas setiap komponen dalam aplikasi pembelajaran Tari Topeng. Hasil pengujian black box seperti terlihat pada Tabel 1 .

Tabel 1. Pengujian Fungsionalitas

\begin{tabular}{|c|c|c|c|}
\hline No & $\begin{array}{l}\text { Komponen } \\
\text { Pengujian } \\
\end{array}$ & Hasil yang diharapkan & Hasil \\
\hline 1 & $\begin{array}{l}\text { Memulai } \\
\text { aplikasi dengan } \\
\text { menekan ikon } \\
\text { media } \\
\text { pembelajaran } \\
\text { pada } \\
\text { smartphone }\end{array}$ & $\begin{array}{l}\text { Menampilkan halaman } \\
\text { menu utama setelah } \\
\text { tampilan screen splash } \\
\text { bertuliskan "Media } \\
\text { Pembelajaran Tari } \\
\text { Topeng" dengan durasi } 5 \\
\text { detik }\end{array}$ & sesuai \\
\hline 2 & $\begin{array}{l}\text { Penguji tombol } \\
\text { sejarah }\end{array}$ & $\begin{array}{l}\text { Pada halaman menu } \\
\text { utama saat tombol sejarah } \\
\text { dipilih selanjutnya akan } \\
\text { menampilkan halaman } \\
\text { materi sejarah dan } \\
\text { perkembangan Tari } \\
\text { Topeng }\end{array}$ & sesuai \\
\hline 3 & $\begin{array}{l}\text { Penguji tombol } \\
\text { deskripsi }\end{array}$ & $\begin{array}{l}\text { Pada halaman menu } \\
\text { utama saat tombol } \\
\text { deskripsi dipilih akan } \\
\text { menampilkan menu } \\
\text { deskripsi tari, selanjutkan } \\
\text { jika diklik salah satu } \\
\text { pilihan tombol deskripsi } \\
\text { tari akan menampilkan } \\
\text { deskripsi tarian }\end{array}$ & Sesuai \\
\hline 5 & $\begin{array}{l}\text { Pengujian } \\
\text { tombol Jenis } \\
\text { tari }\end{array}$ & $\begin{array}{l}\text { Menampilkan sub menu } \\
\text { jenis topeng, jika diklik } \\
\text { salah satu pilihan tombol } \\
\text { akan menampilkan jenis } \\
\text { tari dan topeng yang } \\
\text { digunakan pada tarian }\end{array}$ & sesuai \\
\hline 6 & $\begin{array}{l}\text { Pengujian } \\
\text { tombol video }\end{array}$ & $\begin{array}{l}\text { Menampilkan pilihan } \\
\text { menu video tarian topeng, } \\
\text { dan video akan } \\
\text { ditayangkan bila diklik } \\
\text { salah satu video tarian } \\
\text { yang dinginkan }\end{array}$ & sesuai \\
\hline 7 & $\begin{array}{l}\text { Pengujian } \\
\text { tombol lokasi }\end{array}$ & $\begin{array}{l}\text { Menampilkan peta } \\
\text { Cirebon beserta lokasi } \\
\text { dan nama sanggar seni } \\
\text { yang ada di Cirebon }\end{array}$ & Sesuai \\
\hline 8 & $\begin{array}{l}\text { Pengujian } \\
\text { tombol kuis }\end{array}$ & $\begin{array}{l}\text { Menampilkan pertanyaan } \\
\text { yang pertama }\end{array}$ & Sesuai \\
\hline 9 & $\begin{array}{l}\text { Pengujian } \\
\text { tombol } \\
\text { pertanyaan } \\
\text { selanjutnya }\end{array}$ & $\begin{array}{l}\text { Menampilkan pertanyaan } \\
\text { berikutnya pada halaman } \\
\text { kuis }\end{array}$ & sesuai \\
\hline 10 & $\begin{array}{l}\text { Pengujian } \\
\text { pertanyaan yang } \\
\text { terakhir }\end{array}$ & $\begin{array}{l}\text { Menampilkan nilai skore } \\
\text { kamu }\end{array}$ & sesuai \\
\hline 11 & $\begin{array}{l}\text { Pengujian } \\
\text { tombol keluar }\end{array}$ & $\begin{array}{l}\text { Aplikasi akan keluar dari } \\
\text { halaman kuis dan } \\
\text { menampilkan halaman } \\
\text { menu utama }\end{array}$ & sesuai \\
\hline
\end{tabular}

Dari hasil pengujian black box didapatkan bahwa pada halaman pertama, halaman menu utama, halaman sub menu deskripsi, halaman sub menu jenis tari, halaman sub menu video, halaman lokasi, dan halaman kuis telah berhasil dan berjalan sesuai dengan fungsionalitasnya dengan baik.

Pengujian selanjutnya dilakukan untuk mengetahui kualitas dari aplikasi yang akan diuji. Pengujian kepada 15 
reponden menggunakan kuisioner dengan jawaban menggunakan skala likert, dengan tujuan untuk mengetahui kemampuan aplikasi yang telah dibangun.

Langkah awal pengujian ini dilakukan dengan cara menginstal aplikasi ke smartphone android semua responden untuk menjalankan dan menguji aplikasi kesemua smartphone yang digunakan responden.

Tahapan untuk pengujian aplikasi ini meliputi :

a) pengguna menginstal aplikasi media pembelajaran Tari Topeng ke smartphone android.

b) pengguna menjalankan aplikasi

c) pengguna mengakses menu utama dan fitur yang tersedia pada aplikasi.

Tahapan selanjutnya responden memberikan jawaban atas hasil pengujian setelah mengakses aplikasi yang disediakan. Berikut hasil pengujiannya seperti pada gambar 15 , menunjukan pernyataan atas jawaban bahwa responden setuju dengan aplikasi pembelajaran yang telah dikembangkan untuk diterapkan dalam memberikan pengenalan dan ketrampilan Tari Topeng.

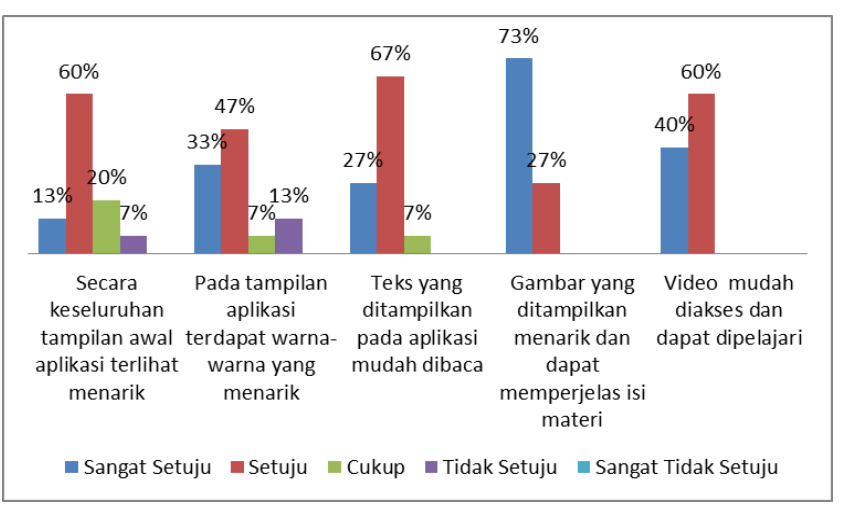

Gambar 15. Hasil pengujian aplikasi

\section{Kesimpulan}

Kesenian tradisional perlu dijaga kelestraiannya oleh penerus bangsa, namun tidak semua perduli dengan keberadaan Tari Topeng Cirebon, untuk membantu memudahkan pengenalan dan pemahaman terhadap Tari Topeng pada penelitian ini dikembangkan media pembelajaran Tari Topeng bagi generasi muda dengan didukung pengoperaian sistem menggunakan smartphone android, pengembangan aplikasi menggunakan metode ADDIE melalui tahapanitahapan yaitu tahapan analysis, design, development, implementation dan evaluation. Hasil penelitian ini adalah aplikasi media pembelajaran Tari Topeng berbasis android untuk mengenalkan Tari Topeng mulai dari sejarah, deskripsi, jenis tari, cara menari Tari Topeng, dan kuis untuk mengevalusi pemahaman pembelajaran,

Untuk mendapatkan kualitas media pembelajaran berbasis android dilakukan pengujian terhadap fungsi aplikasi dengan metode block box dan hasilya dinyatakan bahwa fungsi pada aplikasi dapat berjalan sesuai dengan fungsionalitasnya, dari hasil analisis data pengujian kepada responden diperoleh nilai sebesar $84,27 \%$ dengan kriteria baik terhadap aplikasi sehingga aplikasi ini dapat digunakan sebagai media pembelajaran Tari Topeng.

\section{Ucapan Terimakasih}

Terima kasih kepada Kementrian RISTEK-BRIN yang telah mendanai penelitian ini dalam program Hibah Penelitian Dosen Pemula (PDP) Tahun 2020.

\section{Daftar Pustaka}

[1] T. Sudarto, "Topeng babakan cirebon 1900-1990," greget, vol. 15, no. 2, pp. 128-139, 2016.

[2] U. Kustiawan, "Character Value Education in Cirebon Mask," Int. Acad. J. Soc. Sci., vol. 05, no. 02, pp. 91-98, 2018.

[3] T. Anwari, A. Shodiqin, and A. Priyolistiyanto, "Pengembangan Media Pembelajaran Berbasis Android Pada Pemrograman Dasar Pascal," J. Penelit. dan Pengemb. Pendidik., vol. 4, no. 1, p. 123, 2020.

[4] N. Aminudin et al., "Application program learning based on android for students experiences," Int. J. Eng. Technol., vol. 7, no. 2.27, p. 295, 2018.

[5] C. Meilita Tryana Sembiring, "Peninjauan Prospek Smartphone Global : Studi Pustaka TALENTA Conference Series Peninjauan Prospek Smartphone Global: Studi Pustaka," Energy Eng., vol. 2, no. 3, 2019.

[6] D. P. Mahesi Agni Zaus1, Rizky Ema Wulansari2, Syaiful Islami3, "Perancangan Media Pembelajaran Listrik Statis Dan Dinamis Berbasis Android Designing," J. Inf. Technol. Comput. Sci. Vol., vol. 1, pp. 1-7, 2018.

[7] R. T. A. Kudiasanti and S. Sukirno, "Pengembangan Aplikasi 'Edcounting-App' Sebagai Media Pembelajaran Akuntansi Keuangan," J. Pendidik. Akunt. Indones., vol. 15, no. 1, 2017.

[8] S. Muyaroah and M. Fajartia, "Pengembangan Media Pembelajaran Berbasis Android dengan menggunakan Aplikasi Adobe Flash CS 6 pada Mata Pelajaran Biologi Abstrak," IJCET 6, vol. 6, no. 2301, pp. 79-83, 2017.

[9] I. M. Dhomas Hatta Fudholi, Rahadian Kurniawan, Dimas Panji Eka Jalaputra, "Pengembangan Aplikasi Virtual Reality dengan Model ADDIE untuk Calon Tenaga Pendidik Anak dengan Autisme," J. Resti, vol. 1, no. 10, 2020.

[10] A. F. Mustapid Amna, Rasyid Hardi Wirasasmita, "Pengembangan Media Pembelajaran Berbasis Android Pada Mata Kuliah Sistem Operasi Di Universitas Hamzanwadi," Edumatic, vol. 2, no. September 2016, pp. 17, 2018.

[11] D. Fatmala, U. Yelianti, S. Pengajar, P. Pendidikan, and B. Universitas, "Pengembangan Media Pembelajaran Multimedia Interaktif Berbasis Android Pada Materi Plantae Untuk Siswa Sma Menggunakan Eclipse Galileo Development," BODIK, vol. 2, no. 1, 2016.

[12] S. Bakhri, "Animasi Interaktif Pembelajaran Huruf dan Angka Menggunakan Model ADDIE," INTENSIF J. Ilm. Penelit. dan Penerapan Teknol. Sist. Inf., vol. 3, no. 2, p. 130, 2019.

[13] A. M. Ade Suryanda, Ernawati, "Pengembangan Modul Multimedia Mobile Learning Dengan Android Studio 4.1 Materi Keanekaragaman Hayati Bagi Siswa SMA Kelas X," Biol. J. Pendidik., vol. 9, no. 1, pp. 55-64, 2016.

[14] N. Ibrahim, "Pengembangan Media Pembelajaran Mobile Learning Berbasis Android Mata Pelajaran IPA Untuk Siswa SMP," J. Refleks. EDUKATIKA, vol. 8, no. 1, 2017.

[15] K. E. Putri and S. Sahari, "Pengembangan media pembelajaran berbasis android pada mata kuliah pembelajaran terpadu," J. PINUS, vol. 3, no. 1, pp. 32-40, 2017. 